\title{
Sistem Prediksi Transaksi Nasabah Bank Swasta Memanfaatkan Fuzzy Time Interval Sequential Pattern Mining
}

\author{
Titasari Rahmawati \\ Program Studi Manajemen Informatika \\ Institut Informatika Indonesia \\ tita@ikado.ac.id
}

\author{
Supangat \\ Program Studi Teknik Informatika \\ Universitas 17 Agustus 1945 Surabaya \\ supangat@untag-sby.ac.id
}

\begin{abstract}
Abstrak - Layanan perbankan saat ini memang dirancang sebagai salah satu cara untuk memuaskan para nasabah. Pelayanan operasional adalah pelayanan yang penting karena terjadi secara langsung. Kebutuhan seorang nasabah yang terjadi sewaktu-waktu sehingga bank harus siap dalam hal dana tunai. Transaksi yang terjadi pada sebuah bank tidak dapat diprediksi dengan kasat mata dikarenakan situasi dan kondisi perekonomian yang labil sehingga bank harus memperhatikan jumlah dana tunai yang tersedia. Oleh sebab itu perlu dibangun sebuah sistem prediksi yang dapat memprediksi transaksi nasabah guna untuk mengetahui pada saat momen apa, transaksi apa yang akan dilakukan serta dalam waktu atau tempo yang sebentar, sedang atau lama transaksi kedua akan dilakukan. Sistem ini menggunakan metode fuzzy time interval sequential pattern yang dapat memprediksi transaksi nasabah dikolaborasi dengan momen.
\end{abstract}

Kata Kunci: Fuzzy, Fuzzy Time Interval Sequential Pattern, Momen, Transaksi.

\section{PENDAHULUAN}

Kebutuhan seorang nasabah yang terjadi sewaktu-waktu membuat bank harus siap dalam hal dana tunai. Transaksi yang terjadi pada sebuah bank tidak dapat diprediksi dengan kasat mata dikarenakan kondisi perekonomian yang labil dan kebutuhan nasabah yang sangat cepat berubah dari hitungan waktu ke waktu.

Posisi dana tunai di sebuah bank berpengaruh pada rugi/laba bank. Jika sebuah bank mampu mengelola dana tunai maka tidak akan terjadi kekosongan dana yang menyebabkan bank harus berhutang ke bank lain dan menyebabkan bunga.

Selain itu dana yang menganggur mengakibatkan biaya yang dikeluarkan oleh bank lebih besar dari penerimaan yang didapat dari penerimaan bunga untuk kredit yang diberikan kepada nasabah. Dana masyarakat tersebut dihimpun dalam sebuah dana pihak ketiga (DPK) yang nantinya DPK ini dapat menjadi acuan pihak bank untuk mengelola kebijakan dan likuiditasnya.
Pendapatan pada sisi pasiva harus mampu memenuhi kewajiban kepada nasabah setiap simpanan mereka yang ada di bank, sedangkan pada sisi aktiva bank harus menyanggupi pencairan kredit yang telah diperjanjikan. Supaya bank tidak terjadi kelebihan atau kekurangan dana, bank perlu mengatur dananya secara terencana dan tepat karena efek kelebihan maupun kekurangan dana kedua-duanya tidak menguntungkan bagi bank. Bank dituntut mengelola likuiditas dengan memperhatikan prinsip kehati-hatian dengan memprioritaskan pada pemeliharaan cadangan likuiditas yang sehat. Dengan mengetahui dana tunai masuk dan dana tunai keluar nasabah yang akan datang maka sebuah bank dapat lebih berhati-hati dalam menentukan kebijakan ke depannya. Oleh sebab itu perlu dibangun sebuah sistem yang dapat memprediksi transaksi nasabah guna untuk mengetahui pada saat momen apa, transaksi apa yang akan dilakukan serta dalam interval waktu yang sebentar, sedang atau lama transaksi selanjutnya akan dilakukan.

\section{METODOLOGI PENELITIAN}

\section{A. Sequential Pattern}

Sequential pattern adalah pola yang menggambarkan urutan waktu terjadinya suatu peristiwa. Pola tersebut dapat ditemukan apabila data yang disimpan relatif besar dan peristiwa yang berurutan terjadi beberapa kali. Sequential pattern mining pertama kali diperkenalkan oleh Agrawal dan Srikant pada tahun 1995. Masalah dalam sequential pattern mining sangat berkaitan erat dengan frequent pattern mining, perbedaan utamanya adalah isi dari item yang disusun secara sekuensial [1]. Proses pencarian pola sequential pattern dapat dilihat pada gambar 1 . Sebuah sequence database, $\mathrm{D}=$ $\left\{\mathrm{s}_{1}, \mathrm{~s}_{2}, \mathrm{~s}_{3}, \ldots \mathrm{s}_{\mathrm{n}}\right\}$ adalah himpunan sequence. Setiap sequence dihubungkan dengan id, misalnya id dari $\mathrm{s}_{\mathrm{i}}$ adalah i. $|\mathrm{D}|$ menunjukkan banyaknya sequence dalam database $\mathrm{D}$. Jumlah dari sequence dalam sebuah item disebut dengan panjang item atau l-sequence (length sequence) [2]. Panjang dari sequence ini dilambangkan dengan $|\alpha|$.

Dalam sequential pattern dikenal dengan istilah support sequence. Support sequenced adalah banyaknya sequence 
dalam database D yang memuat $\alpha$, support $(\alpha)=\mid\{\mathrm{s} \mid \mathrm{s} \in \mathrm{D}$ dan $\alpha \subseteq \mathrm{s}\} \mid$ [3].

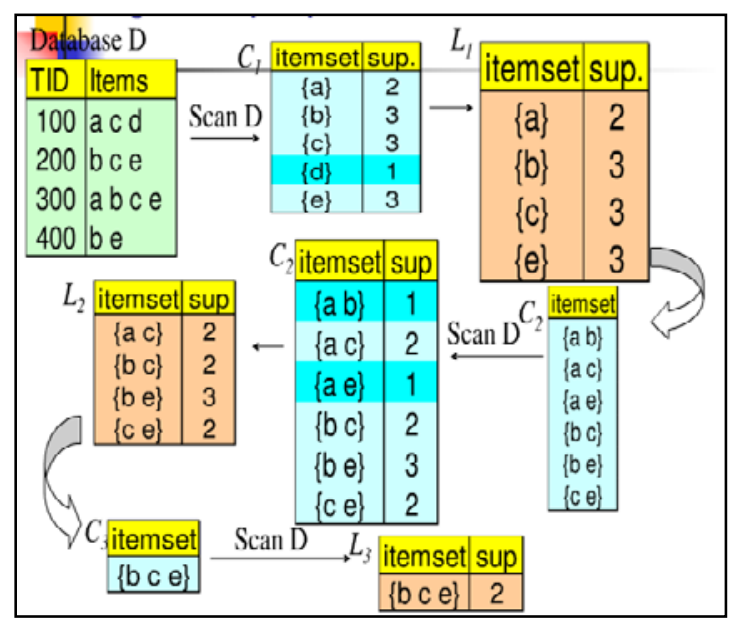

Gambar 1. Proses Algoritma Apriori All

Minimum support adalah batas jumlah minimal dari suatu itemset yang frequent. Frequent sequence pattern berisi semua sequence yang memiliki nilai support yang tidak lebih rendah dari minimum support yang telah ditentukan.

Berdasarkan spesifikasi sequential pattern yang dihasilkan, proses sequential pattern mining pada penelitian ini menggunakan open sequential pattern mining. Open sequential pattern mining (opsp) adalah proses mining yang menghasilkan seluruh pola yang memenuhi threshold yang terdapat di dalam data sedangkan close sequential pattern mining (closp) menghasilkan pola-pola sedemikian rupa sehingga tidak ada suatu pola yang merupakan subsequence dengan nilai threshold yang sama dengan supersequence-nya. misalnya algoritma GSP, SPADE dan PrefixSpan [4].

\section{B. Fuzzy Time interval Sequential Pattern}

Pada penelitian ini menggunakan logika fuzzy untuk mengelompokkan waktu transaksi. Logika fuzzy adalah alat yang powerful untuk pengambilan keputusan untuk mengatasi ketidakpastian dan ketidaktelitian data [5]. Karena itu Profesor Lotfi A Zadeh kemudian memperoleh ide untuk menyajikannya dengan menentukan "derajat keanggotaan” (membership function) dari masing-masing variabelnya. Selain itu, fuzzy juga sesuai diterapkan untuk menangani data numerik dengan menggunakan interval [6].

Untuk mendapatkan pola dari sebuah item transaksi dimana dalam pola tersebut juga mengandung tempo atau lamanya transaksi selanjutnya yang akan terjadi maka peneliti menggunakan beberapa referensi yang ada tentang kolaborasi fuzzy dan sequential pattern mining. Sebelum mengkolaborasikan fuzzy dengan sequential pattern, untuk menentukan besaran waktu dari setiap transaksi peneliti menggunakan metode time interval sequential pattern mining. Time interval sequential pattern mining mempunyai konsep utama dengan membalik setiap urutan asli sebuah data atau transaksi dimana itemset terakhir berada di urutan pertama, hal ini mempunyai tujuan untuk meningkatkan efisiensi dalam mencari pola target [7].
Setelah mendapatkan pola dengan menggunakan time interval sequential pattern kemudian hasil pola tersebut dikelompokkan rentang waktu dari tiap transaksi dengan menggunakan fuzzy. Fuzzy yang dikolaborasikan dengan time-interval sequential pattern mining adalah salah satu jenis teknik data mining yang berguna yang menemukan pola perilaku pelanggan dari waktu ke waktu [8]. Fuzzy time interval sequential pattern dicontohkan dalam sebuah pola belanja berikut (Bread, Short, Milk, Long, Jam) berarti bread dibeli sebelum milk dalam periode Short, dan jam dibeli setelah milk dalam periode long, di mana short dan long adalah istilah linguistik yang telah ditentukan sebelumnya.

Dalam penelitian ini, untuk mempresentasikan time interval dengan digunakan 3 linguistik term yaitu short (S), middle (M), dan long (L) dengan parameter bulan. Mempertimbangkan bahwa 1 bulan terdapat 30 hari, short linguistik variabel dapat didefinisikan jika time interval yang diantara dua event yang pertama dimana kurang dari atau sama dengan dua hari kemudian mereka dengan pasti dimasukkan dalam sequence dan mempunyai nilai derajat keanggotaan 1 dan jika time interval tidak lebih dari 15 hari kemudian nilai derajat keanggotaan dihitung berdasarkan lekukan garis diantara 2 dan 15 . Jika time interval adalah lebih dari 15 sehingga tidak dapat direpresentasikan ke dalam variabel short jadi nilai derajat keanggotannya adalah 0. Dengan cara yang sama, dapat ditentukan nilai linguistik untuk middle dan long. Derajat keanggotaan atau yang disebut membership function dapat direpresentasikan dengan persamaan (1), (2), dan (3). Membership function dalam penelitian ini dapat dilihat pada gambar 2 .

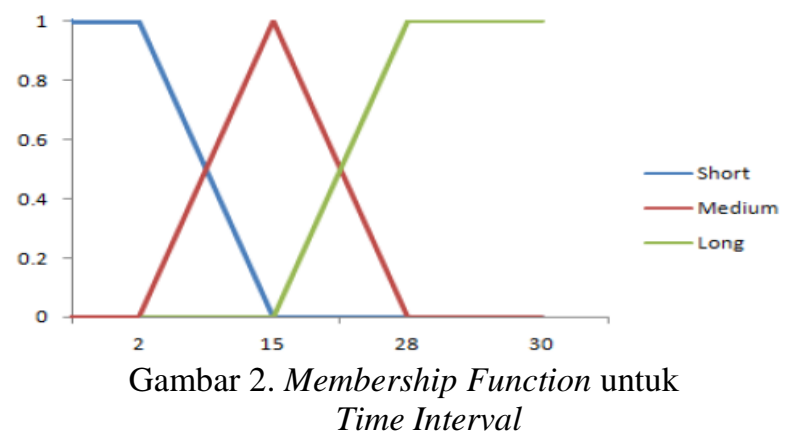

Dari gambar 2 ditransformasikan ke dalam bentuk persamaan untuk mencari linguistik term short, middle dan long. Persamaan tersebut dapat dilihat pada persamaan 1, 2 dan 3.

$$
\begin{aligned}
& \mu_{\text {short }}\left(\mathrm{ti}_{\mathrm{j}}\right)=\left\{\begin{array}{l}
1 ; \mathrm{tij}_{\mathrm{j}} \leq 2 \\
\frac{15-\mathrm{tij}_{\mathrm{j}}}{13} ; 2 \leq \mathrm{ti}_{\mathrm{j}} \leq 15 \\
0 ; \mathrm{tij}_{\mathrm{j}} \geq 15
\end{array}\right. \\
& \mu_{\text {middle }}\left(\mathrm{ti}_{\mathrm{j}}\right)=\left\{\begin{array}{l}
0 \quad ; 2 \geq \mathrm{t}_{\mathrm{ij}} \text { or } \mathrm{tij}_{\mathrm{ij}} \geq 28 \\
\frac{\mathrm{tij}-2}{13} ; 2<\mathrm{t}_{\mathrm{ij}} \leq 15 \\
\frac{28-\mathrm{tij}_{\mathrm{ij}}}{13} ; 15<\mathrm{tij} \leq 28
\end{array}\right.
\end{aligned}
$$


$\mu_{\text {long }}\left(\mathrm{ti}_{\mathrm{j}}\right)= \begin{cases}0 & ; \mathrm{t}_{\mathrm{ij}} \leq 15 \\ \frac{\mathrm{t}_{i j}-15}{13} & ; 15<\mathrm{tij}_{\mathrm{ij}}<28 \\ 1 & ; \mathrm{t}_{\mathrm{ij}} \geq 28\end{cases}$

Jika sequence $\alpha$ berisi dengan derajat $\gamma$ maka disebut Fuzzy Time Interval (FTI) dengan subsequence S dengan derajat $\gamma$ [9]. Total jumlah pola FTI sequence $\alpha$ disebut panjangnya sequence. FTI sequence yang mempunyai panjang $\mathrm{k}$ disebut dengan fuzzy $\mathrm{k}$ time-interval sequence.

supports $(\alpha)=\sum($ sid,s)in s

support_count $\mathrm{S}(\alpha)=\{(\operatorname{sid}, \mathrm{s}) \mid(\operatorname{sid}, \mathrm{s}) \in \mathrm{S} \wedge \alpha$ berada dalam $\mathrm{s}\}$ confidences $(\alpha 1 \geq \alpha 2)=$

support $_{\text {count }}(\alpha 1 \geq \alpha 2)$

support count $(\alpha 1)$

\section{Metode Fuzzy Time Interval Sequential Pattern}

Metode fuzzy time interval sequential pattern diadopsi dari algoritma AprioriAll karena menggunakan property dari apriori. Pada gambar 3 adalah skema dari proses fuzzy time interval sequential pattern yang dilahirkan dari proses algoritma AprioriAll. Dimulai dari pembangkitan database sampai pada penurunan kandidat sequence 1 sampai sequence 2 beserta minimum support yang akhirnya akan menjadi itemset yang terpilih karena minimum support yang sudah ditentukan. Algoritma FTI-Apriori dapat dilihat pada algoritma berikut ini:

1: Input : Sequence Database = S, Min Supp = min_sup, Linguistic Terms $=\mathrm{LT}$

2: Output : Set Pola Fuzzy Time Interval

3: Variable : c.count adalah support time interval dari sequence $\mathrm{c}$

4: $\mathrm{C} 1=$ temukan semua item (S)

5: $\mathrm{L} 1=\mathrm{c} \in \mathrm{C} 1 \mid \mathrm{c}$.count $\geq$ min_sup

6: For each $i 1 \epsilon \mathrm{L} 1$

7: For each $i 2 \epsilon \mathrm{L} 1$

8: For each 1 td $\epsilon \mathrm{Lt}$

9: $\mathrm{c}=\mathrm{i} 1 * \operatorname{ltd} * \mathrm{i} 2$

10: tambahkan c ke C2

11: L2 $=\mathrm{c} \in \mathrm{C} 2$ dan c.count min_sup

12: For $\mathrm{k}>2$ dan $\mathrm{Lk}-1 \neq \epsilon$ maka

13: Ck = fuzzy_apriori_gen (Lk-1)

14: Membangun kandidat CK

15: For each sequence $\mathrm{s} \in \mathrm{S}$

16: hitung support kandidat fuzzy

17: $\mathrm{Lk}=\mathrm{c} \epsilon \mathrm{Ck}$ dan c.count/S $\geq$ min_sup

18: menggabung nilai dari Lk

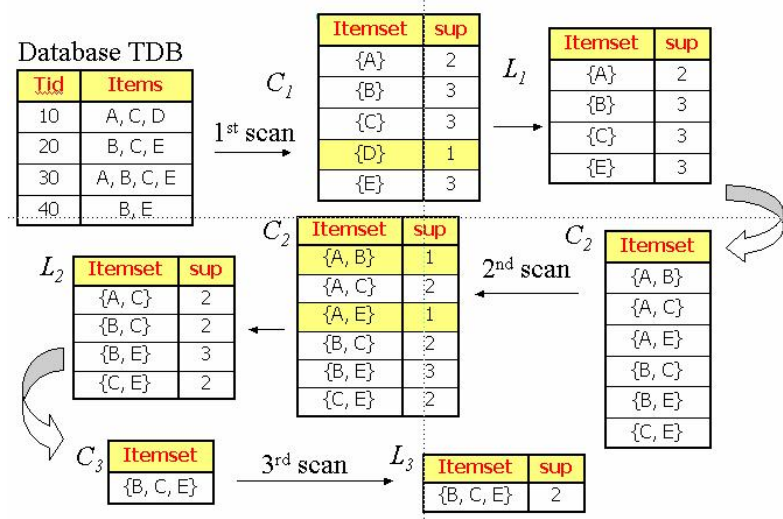

Gambar 3. Proses Algoritma AprioriAll

Algoritma FTI-Apriori diadopsi dari algorirma Apriori sehingga mempunyai tahap proses seperti pada gambar 3 . Dari seluruh items yang diurutkan berdasarkan TID (transaction ID) dipetakan per item berdasarkan jumlah support yang akan masuk ke dalam kandidat 1 (C1), kemudian dalam large itemset 1 adalah membuang itemset yang tidak memenuhi support, selanjutnya pada kandidat itemset 2 (C2) adalah menyusun itemset menjadi sequence 2 dengan masing-masing jumlah support untuk dimasukkan ke dalam large itemset 2 dimana itemset yang tidak memenuhi support harus dibuang sampai pada pembentukan kandidat itemset 3 (C3). Inilah dasar dari algoritma FTIApriori kemudian tahap selanjutnya adalah memproses masing-masing itemset dengan fuzzy time interval. Berikut ini adalah proses dari algoritma FTI-Apriori:

1. $\mathrm{C} 1=$ temukan semua item (S)

Mencari C1 yaitu mencari jumlah item dari data sequence.

2. $\mathrm{L} 1=\left\{\mathrm{c} \in \mathrm{C} 1 \mid \mathrm{c} . \mathrm{count} \geq \min \_\right.$sup $\}$

Mencari L1 dari anggota $\bar{C} 1$ atau item support yang lebih besar dari minimal support :

3. Mencari C2 dari anggota L1 yang telah dijoinkan dengan Linguistic Term.

4. L2= cєC2 dan c.count $\epsilon$ min_sup

Mencari L2 dari anggota C2 atau item support yang lebih besar dari minimal support dimana kita telah mendapatkan pola L2 dengan linguistik term-nya dari proses sebelumnya.

5. Mencari C3 dari anggota L2 yang telah dijoinkan dengan Linguistic Term yang telah terbentuk dari L2.

\section{Data Penelitian}

Data yang digunakan di dalam penelitian ini adalah termasuk dalam data primer dan data sekunder. Data primer didapatkan dari hasil wawancara dengan Operational Manager bank dan wawancara kepada beberapa nasabah yang diambil secara acak. Untuk mendapatkan data sekunder peneliti melakukan permohonan permintaan data ke bagian EDP (Electronic Data Processing) karena di bagian EDP merupakan bagian pemrosesan data dan menghimpun datadata transaksi dari tahun diadakannya transaksi sampai saat ini. Peneliti melakukan berbagai prosedur ijin untuk mendapatkan data yang dibutuhkan dikarenakan data 
nasabah dan data transaksi merupakan data yang dijaga kerahasiannya. Data yang didapat berupa transaksi nasabah aktif dari tahun 2010 sampai tahun 2016. Data sekunder tersebut berupa data transaksi yang terdiri dari beberapa atribut diantaranya nomor rekening, nama nasabah, jenis transaksi, tanggal transaksi, nominal, dan saldo akhir. Data transaksi nasabah yang telah di-preprocessing dapat dilihat pada tabel 1 .

Data transaksi nasabah adalah hasil proses cleaning dan pengkategorian transaksi dengan memanfaatkan SQL Server 2011. Pada data tersebut, ada beberapa atribut yang tidak diperlukan dan harus dibuang misalnya userid, userap, kdpost, kdpostlawan, dc, dc lawan, print buku dan tipe tabungan. Kemudian data transaksi nasabah akan dikategorikan jenis transaksinya berdasarkan besarnya jumlah transaksi. Jenis transaski akan dikategorikan menjadi 12 tipe transaksi berdasarkan jumlah nominal transaksi. Jenis transaksi sesuai dataset terbagi menjadi ST (setor tunai), TT (tarik tunai), CNT (credit nota transfer), DNT (debit nota transfer). Untuk melihat detil kategori jenis transaksi dapat dilihat pada tabel 1 .

Data yang telah selesai dilakukan preprocessing kemudian di-export ke M. Excel 2007 kemudian disimpan dengan format csv. Kemudian peneliti juga membutuhkan data momen yang digunakan untuk mengetahui momen transaksi karena momen adalah sesuatu yang berkaitan dengan masa yang terjadi dalam kurun waktu yang tidak lama. Data momen didapatkan dari hasil wawancara dengan para nasabah dan dikoordinasikan dengan operational manager sehingga didapatkan data momen yang sesuai.

Tabel 1. Kategori Jenis Transaksi

\begin{tabular}{lll}
\hline Jenis Transaksi & Nominal (Rp) & Kategori \\
\hline \multirow{3}{*}{ Setor } & $<1.000 .000$ & STK \\
\cline { 2 - 3 } & $=1.000 .000-10.000 .000$ & STS \\
\cline { 2 - 3 } Tarik & $>=10.000 .000$ & STB \\
\cline { 2 - 3 } & $=1.000 .000$ & TTK \\
\cline { 2 - 3 } Transfer Antar & $>=10.000 .000-10.000 .000$ & TTS \\
(Pindah Buku) & $<5.000 .000$ & TTB \\
\cline { 2 - 3 } & $=5.000 .000-50.000 .000$ & DNTPBS \\
\cline { 2 - 3 } Transfer Antar Bank & $>=50.000 .000$ & DNTPBB \\
\cline { 2 - 3 } Transfer Masuk dari Rekening & $>1.000 .000$ & DNTK \\
\cline { 2 - 3 } Lain & $=1.000 .000-10.000 .000$ & DNTS \\
\cline { 2 - 3 } & $>=10.000 .000$ & DNTB \\
\cline { 2 - 3 } & $=5.000 .000$ & CNTPBK \\
\cline { 2 - 3 } Transfer Masuk dari Bank Lain & $>=50.000 .000$ & CNPBS \\
\cline { 2 - 3 } & $>1.000 .000$ & CNTSB \\
\cline { 2 - 3 } & $>=1.000 .000-10.000 .000$ & CNTS \\
\hline
\end{tabular}

Tabel 2. Sample Data Nasabah

\begin{tabular}{ccclcrrr}
\hline No Trans & $\begin{array}{c}\text { Tanggal } \\
\text { Trans }\end{array}$ & No Rek & Nama Nasabah & $\begin{array}{c}\text { Jenis } \\
\text { Trans }\end{array}$ & $\begin{array}{c}\text { Detil } \\
\text { Trans }\end{array}$ & Debet & Kredit \\
\hline 1 & $20 / 12 / 2011$ & 20070 & Titis Rufaidah & ST & STS & 0 & 5000000 \\
\hline 2 & $22 / 12 / 2011$ & 2265 & R Nasrudin & TT & TTS & 1260000 & 0 \\
\hline 3 & $22 / 12 / 2011$ & 2249 & Rahmad Nasirudin II & ST & STS & 0 & 1260000 \\
\hline 4 & $24 / 12 / 2012$ & 2239 & Nur Ibadi KUA & TT & TTK & 500000 & 0 \\
\hline 5 & $26 / 12 / 2012$ & 2339 & Ach. Zainuddin & ST & STK & 0 & 200000 \\
\hline 6 & $26 / 12 / 2012$ & 20129 & Fibriani & ST & STK & 0 & 500000 \\
\hline 7 & $26 / 12 / 2012$ & 2324 & Maziyah & TT & TTS & 1000000 & 0 \\
\hline 8 & $22 / 01 / 2013$ & 2231 & Ninis Maftuhatin & ST & STS & 0 & 1020000 \\
\hline 9 & $13 / 08 / 2008$ & 2257 & Sismawati & TT & TTS & 1000000 & 0 \\
\hline 10 & $13 / 08 / 2008$ & 2257 & Sismawati & TT & TTS & 1500000 & 0 \\
\hline 11 & $14 / 08 / 2008$ & 20006 & Endah Sriwilujeng & ST & STS & 0 & 2000000 \\
\hline 12 & $14 / 08 / 2008$ & 20099 & Fibriani & TT & TTK & 245000 & 0 \\
\hline 13 & $15 / 08 / 2008$ & 20144 & Mansuri & TT & TTS & 1000000 & 0 \\
\hline
\end{tabular}


Tabel 3. Sample Data Momen

\begin{tabular}{clcc}
\hline Tanggal & \multicolumn{1}{c}{ Kode } & Tanggal Dari & Tanggal Sampai \\
\hline $06 / 01 / 2011$ & Pascatb & $04 / 01 / 2011$ & $08 / 01 / 2011$ \\
\hline $07 / 02 / 2011$ & Tbimlek & $05 / 02 / 2011$ & $09 / 02 / 2011$ \\
\hline $13 / 03 / 2011$ & Musimpanen & $11 / 03 / 2011$ & $15 / 03 / 2011$ \\
\hline $01 / 09 / 2011$ & Bulan puasa & $30 / 08 / 2011$ & $03 / 09 / 2011$ \\
\hline $01 / 10 / 2011$ & Idulfitri & $29 / 09 / 2011$ & $04 / 10 / 2011$ \\
\hline $08 / 12 / 2011$ & Iduladha & $06 / 12 / 2011$ & $10 / 12 / 2011$ \\
\hline $25 / 12 / 2011$ & Hrnatal & $23 / 12 / 2011$ & $27 / 12 / 2011$ \\
\hline $02 / 03 / 2012$ & Musim panen & $28 / 02 / 2012$ & $04 / 03 / 2012$ \\
\hline $05 / 01 / 2012$ & Pascatb & $03 / 01 / 2012$ & $07 / 01 / 2012$ \\
\hline $26 / 01 / 2012$ & Tbimlek & $24 / 01 / 2012$ & $28 / 01 / 2012$ \\
\hline $18 / 08 / 2012$ & Bulan puasa & $16 / 08 / 2012$ & $20 / 08 / 2012$ \\
\hline $21 / 09 / 2012$ & Idulfitri & $19 / 09 / 2012$ & $24 / 09 / 2012$ \\
\hline $27 / 11 / 2012$ & Iduladha & $25 / 11 / 2012$ & $29 / 11 / 2012$ \\
\hline $18 / 12 / 2012$ & Tbhijriyah & $16 / 12 / 2012$ & $20 / 12 / 2012$ \\
\hline $25 / 12 / 2012$ & Hrnatal & $23 / 12 / 2012$ & $27 / 12 / 2012$ \\
\hline $04 / 01 / 2013$ & Pascatb & $02 / 01 / 2013$ & $06 / 01 / 2013$ \\
\hline
\end{tabular}

Pada proses mengkategorikan transaksi seperti pada penjelasan di atas menggunakan query pada SQL Server 2011. Kemudian setelah dikelompokkan jenis-jenis transaksi pada data transaksi tersebut kemudian data disimpan dengan format CSV. CSV sendiri merupakan data yang menggunakan tanda ',' sebagai pemisah antara kolomkolomnya. Dari proses tersebut didapatkan sebuah tabel baru yang diberi nama m_csv.

\section{E. Teknik Analisa}

Data transaksi berjumlah 32301 record terdiri dari data transaksi pada tahun 2010 berjumlah 5164 transaksi, transaksi pada tahun 2011 berjumlah 7352 transaksi, transaksi pada tahun 2012 berjumlah 7543 transaksi, transaksi pada tahun 2013 berjumlah 4258 transaksi, transaksi pada tahun 2014 berjumlah 7319 transaksi, transaksi pada tahun 2015 berjumlah 624 transaksi, dan pada transaksi 2016 berjumlah 41 transaksi.

Pada penelitian ini, definisi nasabah adalah semua orang yang mempunyai simpanan/nomor rekening di bank. Orang di sini adalah dapat diartikan individu atau kumpulan beberapa individu yang membentuk sebuah badan usaha, organisasi atau badan pemerintah. Nasabah dibedakan menjadi 2 kriteria diantaranya nasabah produktif dan nasabah aktif. Suatu nasabah disebut produktif jika nasabah tersebut memberikan keuntungan kepada bank ketika melakukan transaksi bank. Transaksi tersebut dapat berupa peningkatan frekuensi setoran tunai yang dapat meningkatkan saldo tabungan nasabah. Semakin tinggi saldo nasabah pada suatu periode tertentu akan disebut nasabah yang produktif. Sedangkan nasabah aktif adalah nasabah yang sering melakukan transaksi bank baik setoran ataupun tarikan tanpa memperhitungkan jumlah saldo. Semakin sering nasabah melakukan transaksi bank, maka peluang untuk menjadi nasabah yang aktif semakin besar.

Pada penelitian ini data nasabah yang digunakan adalah data nasabah aktif, disebut nasabah aktif jika jumlah keseluruhan transaksi per triwulan lebih dari 15 (lima belas) transaksi selama satu tahun. Dengan demikian nasabah aktif paling tidak akan melakukan transaksi bank sebanyak 60 (enam puluh) transaksi selama satu tahun. Nasabah yang tidak termasuk dalam kriteria nasabah aktif termasuk ke dalam jenis nasabah dormant yaitu nasabah yang rekeningnya tidur atau tidak ada mutasi baik penyetoran maupun penarikan selama lebih dari sama dengan 6 bulan. Nasabah yang tergolong dormant tidak digunakan dalam penelitian ini.

Kebutuhan perangkat lunak yang digunakan untuk membangun sistem ini adalah minimal sebagai berikut.

1) Sistem Operasi Windows 7

2) Microsoft Visual Studio 2013

3) Software yang digunakan untuk membangun sistem prediksi pada penelitian ini dengan menggunakan bahasa Visual Basic.

4) SQL Server pada sistem ini digunakan untuk mengolah data mentah yang didapat peneliti dari sumber untuk menjadi data yang siap diolah dan kemudian dilakukan normalisasi data

5) Microsoft Excel 2007

\section{HASIL DAN PEMBAHASAN}

Sebelum dilakukan implementasi sistem, perlu dilakukan analisis dan desain sistem untuk mempermudah implementasi sistem karena sebagai acuan untuk menghasilkan sistem yang baik. Dalam penelitian ini menggunakan flowchart sebagai metode perancangan sistem. Flowchart digunakan untuk menggambarkan alur dari fuzzy time interval sequential pattern dan sebagai acuan dalam merancang sistem. Tahap awal alur dari sistem ini adalah memasukkan dataset transaksi yang telah dilakukan preprocessing berformat CSV kemudian dilanjutkan proses mining yang berupa pembentukan C1, L1, $\mathrm{C} 2$ dengan time interval dan momen, $\mathrm{C} 3$ dengan time interval 
dan momen, kemudian penentuan akurasi. Sesuai dengan gambar 4 di bawah ini bahwa pada ketikadata sudah dimasukkan ke dalam sistem proses selanjutnya adalah memasukkan minimum support yang memiliki rentang 0 sampai dengan jumlah maksimal transaksi.

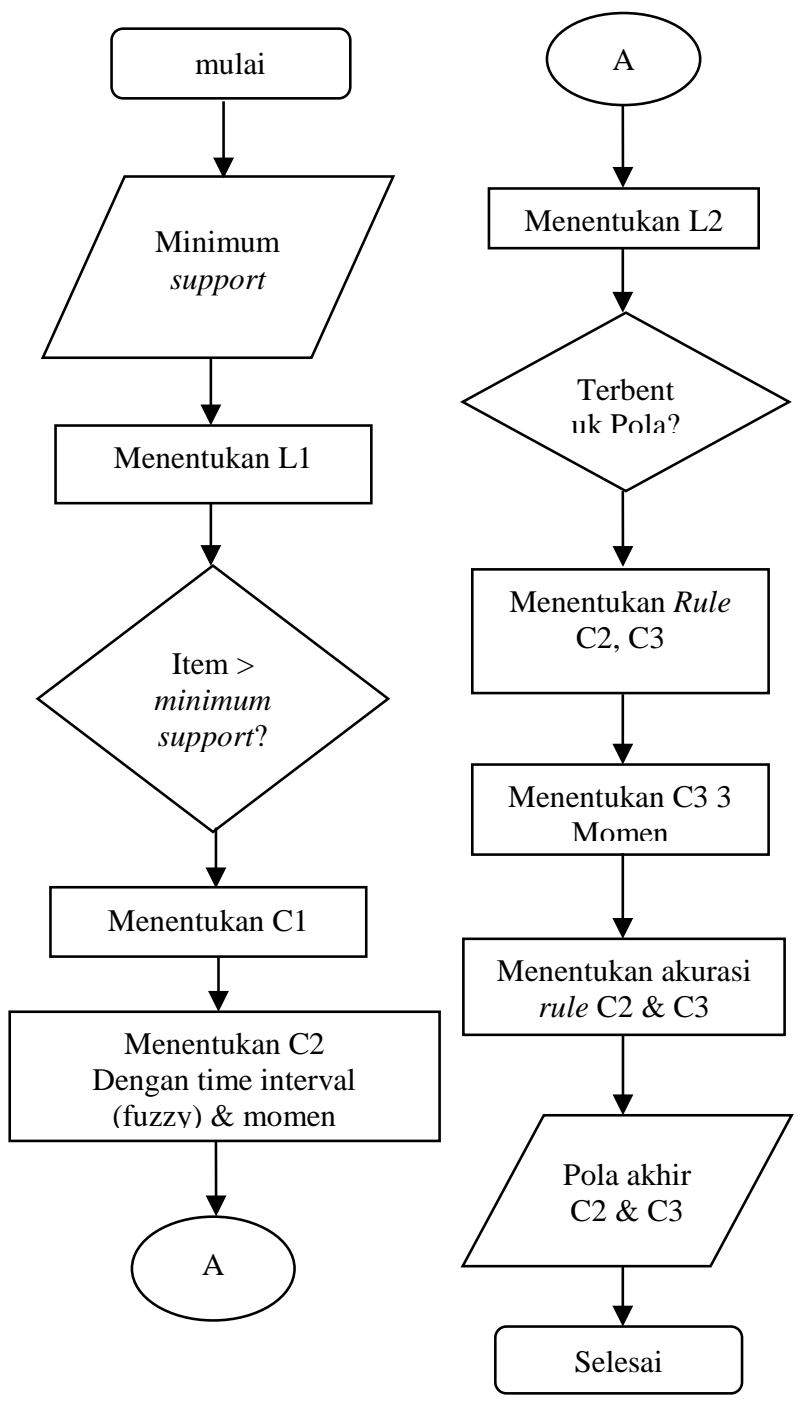

Gambar 4. Flowchart FTI-Sequential Pattern

Tahap kedua menentukan L1 yaitu large itemset 1 yang memiliki support di atas input minimum support. Besarnya support ditentukan oleh user dengan batas maksimalnya adalah sejumlah banyaknya transaksi. Pada tabel L1 terdapat 2 kolom yaitu jenis transaksi dan jumlah (support). Jika terdapat item yang tidak memenuhi minimum support maka tidak akan dimasukkan ke dalam proses mining selanjutnya, sedangkan itemset yang memenuhi akan menjadi kandidat sequence 1 (C1). Pada tabel C1 ini dataset transaksi dibentuk menjadi database sequence yang diurutkan berdasarkan tanggal. Pada tabel C1 terdapat 2 kolom yaitu nomor rekening dan sequence.

Tahap ketiga, jika terdapat item-item yang tidak memenuhi minimum support maka tidak akan dimasukkan ke dalam proses mining selanjutnya, sedangkan itemset yang memenuhi akan menjadi kandidat sequence 1 (C1).

Pada tabel C1 ini dataset transaksi dibentuk menjadi database sequence yang diurutkan berdasarkan tanggal. Pada tabel C1 terdapat 2 kolom yaitu nomor rekening dan sequence. Tahap keempat setelah terbentuk C1 kemudian menentukan C2 dengan kolaborasi time interval dan momen. C2 adalah kandidat sequence yang disusun menjadi 2 bagian item transaksi (jenis transaksi) berdasarkan tanggal transaksi. Kemudian time interval ditentukan berdasarkan interval dari tanggal yang dihitung menggunakan fuzzy serta dikolaborasi dengan momen yang diambil dari data input awal berupa data momen berdasarkan tanggal rentang transaksi pertama dan kedua dalam C2. Momen pada C2 terdapat 2 momen yaitu momen1 dan momen2 sesuai dengan tanggal pertama transaksi dan tanggal kedua transaksi. Dibentuk juga momen antara untuk mengetahui momen diantara tanggal transaksi pertama sampai tanggal transaksi kedua. Pada tabel C2 akan dibentuk 9 kolom yaitu nomor rekening, tanggal transaksi1, tanggal transaksi2, jenis transaksi1, jenis transaksi2, linguistik term, momen transaksi1, momen transaksi2, dan momen antara.

Tahap kelima menentukan L2 yaitu large itemset 2 dengan menentukan time interval tiap pola sesuai dengan algoritma FTI-Apriori. Untuk memudahkan proses penentuan L2, dibentuk pola C2 menjadi tabel terlebih dahulu kemudian menjadi pola L2.

Tahap keenam menentukan pola pada kandidat sequence 3 (C3) dengan menggabung pola yang ada di L2 dengan susunan misalnya (a, short,b) (a, long b) (b long e) maka akan menjadi pola di C3 (a, short, b, long e).

Tahap ketujuh kemudian menyusun C3 dengan momen dimana dengan 3 momen yang diambil dari tiap tanggal yang menyusun C3. C3 3 momen di sini adalah membentuk C2 menjadi 3 sequence. Pada tabel C3 3 momen akan terdapat kolom yaitu nomor rekening, tanggal transaksi1, tanggal transaksi2, tanggal transaksi3, jenis transaksi1, jenis transaksi2, jenis transaksi3, momen transaksi1, momen transaksi2, dan momen transaksi3 serta momen antara.

Tahap kedelapan menentukan akurasi masing-masing rule dengan menentukan minimum support dan cconfidence di tiap-tiap rule baik C2 dan C3.

Hasil menunjukkan bahwa akurasi rule dengan kombinasi support dan confidence yang diuji cobakan berbeda-beda dengan perbandingan akurasi rule menggunakan momen antara dan dengan momen per item menunjukkan hasil yang lebih tinggi dengan menggunakan momen per item. Hasil dari perbandingan akurasi rule dapat dilihat pada gambar 5 . 


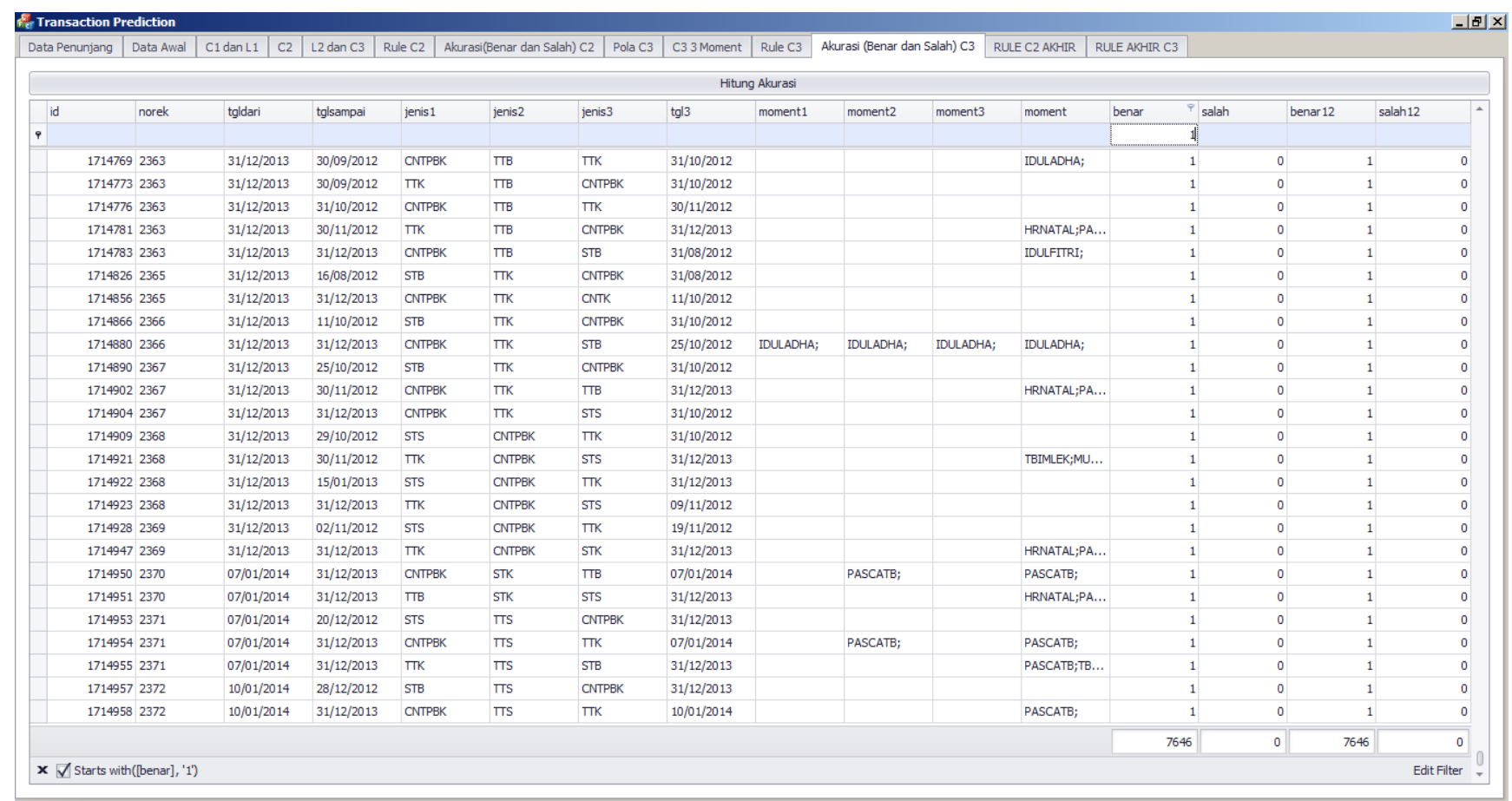

Gambar 5. Hasil Perbandingan Akurasi Rule

Peneliti menggunakan akurasi dengan momen per item sebagai acuan untuk menghitung akurasi sistem ini. Momen antara memiliki hasil akurasi lebih kecil dibandingkan dengan menggunakan momen per item dikarenakan sebuah rule atau pola yang memiliki momen antara masih bersifat umum yang berarti tiap rule atau pola meskipun memiliki rule atau pola yang sama namun memiliki momen antara yang berbeda karena rentang tanggal transaksi yang berbeda. Berbeda dengan momen per item dimana setiap rule atau pola memiliki momen per item yang dibedakan di setiap tanggal transaksi dimana rule atau pola lebih detail sehingga mendukung kecocokan rule dengan data yang ada. Hasil perbandingan akurasi sistem dengan pemberian nilai support dan confidence yang berbeda-beda (4 x uji coba) maka dapat disimpulkan dalam sebuah tabel akurasi rule C2 sistem prediksi yang dapat dilihat pada Tabel 4 dan Tabel 5.

Dari Tabel di 4 dan 5 dapat disimpulkan bahwa tingkat akurasi tertinggi adalah pada support dan confidence 0\% dan $5 \%$ yaitu pada minimum jumlah data yang sesuai dengan pola adalah 1 data dengan jumlah data yang prediksi benar sebesar 1893114 dan jumlah data prediksi salah adalah sebesar 16166 sehingga menghasilkan tingkat akurasi sebesar 99,15\% dengan hasil akhir rule C2 sebanyak 14761 rule. Untuk hasil akhir rule dengan akurasi 77,01\% adalah sebagai berikut :

- IF TTK (-) LONG (-) THEN CNTPBK CONF = 53,66\% ; SUPP $=9,59 \%$

- IF TTK (-) LONG (-) THEN TTK CONF = 26,34\% ; SUPP $=4,7 \%$

- IF TTK (-) LONG (-) THEN TTB CONF = 12,67\% ; SUPP $=2,26 \%$

- IF TTB (-) LONG (-) THEN TTK CONF = 24,08\% ; SUPP $=4,49 \%$
- IF STS (-) LONG (-) THEN CNTPBK CONF = 45,9\% ; SUPP $=1,65 \%$

- IF CNTPBK (-) LONG (-) THEN CNTPBK CONF = $54,04 \%$; SUPP $=22,58 \%$

- IF STK (-) LONG (-) THEN CNTPBK CONF = 44,31\% ; SUPP $1,17 \%$

- IF TTS (-) LONG THEN (-) CNTPBK CONF = 43,82\% ; SUPP $=1,63 \%$

- IF CNTPBK (-) LONG (-) THEN TTB CONF=13,9\% ; SUPP $=5,81 \%$

- IF TTB (-) LONG THEN CNTPBK CONF=51,71\% ; SUPP $=9,65 \%$

- IF CNTPBK (-) LONG (-) THEN TTK CONF = 25,32\% SUPP $=10,58 \%$

- IF TTB (-) LONG (-) THEN TTB CONF=15,57\% ; SUPP $=2,9 \%$

Pada hasil akhir rule di atas kebetulan tidak terdapat momen yang terjadi pada pola transaksi tersebut sehingga semua pola bermomen (-). Pada rule baris ketiga di atas yaitu rule IF TTK (-) LONG (-) THEN TTB CONF = $12,67 \%$; SUPP $=2,26 \%$ yang berarti dimana tarik tunai kecil dengan rentang nominal dari Rp. 50.000,00 sampai dengan kurang dari sama dengan Rp 1.000.000,00 kemudian dalam interval long yang memiliki interval lebih dari 2 hari atau lebih dari 28 hari atau diantara 2 sampai 15 hari atau diantara 15 sampai 28 hari akan terjadi transaksi tarik tunai besar dengan rentang nominal lebih dari Rp.10.000.000,00. Pola ini sangat berarti untuk pihak bank untuk mengambil keputusan dalam menyiapkan dana tunai sehingga bagian operasional mempunyai acuan berapa dana tunai yang harus siap untuk tanggal-tanggal tertentu. 
Tabel 4. Perbandingan Hasil Akurasi Sistem Prediksi Pada Rule C2 dengan Momen Per Item

\begin{tabular}{|c|c|c|c|c|c|}
\hline \multirow[t]{2}{*}{ No } & \multicolumn{2}{|c|}{$\begin{array}{l}\text { Nilai Support dan } \\
\text { Confidence }\end{array}$} & \multirow{2}{*}{$\begin{array}{c}\text { Jumlah Prediksi } \\
\text { Benar }\end{array}$} & \multirow{2}{*}{$\begin{array}{c}\text { Jumlah Prediksi } \\
\text { Salah }\end{array}$} & \multirow[t]{2}{*}{ Akurasi } \\
\hline & Support & Confidence & & & \\
\hline 1 & $2 \%$ & $5 \%$ & 1385420 & 523860 & $71,60 \%$ \\
\hline 2 & $1 \%$ & $10 \%$ & 1470393 & 438887 & $77,01 \%$ \\
\hline 3 & $10 \%$ & $10 \%$ & 633045 & 1276775 & $33 \%$ \\
\hline 4 & $0 \%$ & $5 \%$ & 1893114 & 16166 & $99,15 \%$ \\
\hline
\end{tabular}

Tabel 5. Perbandingan Hasil Akurasi Sistem Prediksi Pada Rule C2 dengan Momen Antara

\begin{tabular}{|c|c|c|c|c|c|}
\hline \multirow[t]{2}{*}{ No } & \multicolumn{2}{|c|}{$\begin{array}{c}\text { Nilai Support dan } \\
\text { Confidence }\end{array}$} & \multirow{2}{*}{$\begin{array}{c}\text { Jumlah Prediksi } \\
\text { Benar }\end{array}$} & \multirow{2}{*}{$\begin{array}{c}\text { Jumlah Prediksi } \\
\text { Salah }\end{array}$} & \multirow[t]{2}{*}{ Akurasi } \\
\hline & Support & Confidence & & & \\
\hline 1 & $2 \%$ & $5 \%$ & 70156 & 1839124 & $3,67 \%$ \\
\hline 2 & $1 \%$ & $10 \%$ & 74484 & 1834796 & $3,91 \%$ \\
\hline 3 & $10 \%$ & $10 \%$ & 29179 & 1880101 & $1,57 \%$ \\
\hline 4 & $0 \%$ & $5 \%$ & 1774071 & 135209 & $92,91 \%$ \\
\hline
\end{tabular}

Tabel 6. Tabel Perbandingan Hasil Akurasi Sistem Prediksi

\begin{tabular}{cccccc}
\hline No & Momen & $\begin{array}{c}\text { Jumlah Minimal Data } \\
\text { (data cocok dengan rule) }\end{array}$ & $\begin{array}{c}\text { Jumlah Prediksi } \\
\text { Benar }\end{array}$ & $\begin{array}{c}\text { Jumlah } \\
\text { Prediksi Salah }\end{array}$ & $\begin{array}{c}\text { Akurasi } \\
\text { (\%) }\end{array}$ \\
\hline 1 & Momen per item & 1 & 7646 & 1265207 & $0,6 \%$ \\
\hline 2 & Tanpa Momen & 1 & 644072 & 628781 & $50,60 \%$ \\
\hline
\end{tabular}

\section{KESIMPULAN}

Berdasarkan analisa hasil penelitian didapatkan beberapa kesimpulan bahwa sistem prediksi dapat menghasilkan rulerule yang digunakan sebagai pertimbangan pihak operasional dalam memprediksi transaksi yang akan terjadi mendatang pada saat momen tertentu. Selain itu dengan dengan metode fuzzy time interval sequential pattern dengan kolaborasi momen tidak hanya pola transaksi yang terprediksi namun momen tiap terjadinya transaksi dapat diprediksi. Kontribusi langsung yang dirasakan pihak operasional adalah dalam hal menyiapkan dana tunai jika sewaktu-waktu terjadi penarikan jumlah tertentu dalam momen tertentu.

Untuk menentukan batas nilai support dan confidence dalam menghasilkan jumlah rule dan besar akurasi rule yang dihasilkan sistem maka peneliti melakukan beberapa kali uji coba nilai support dan confidence sehingga dihasilkan akurasi dan kesimpulan yang konsisten. Dimana akurasi tercapai maksimum jika nilai support diturunkan begitu juga untuk nilai confidence. Artinya semakin kecil nilai support dan nilai confidence maka akan menghasilkan lebih banyak rule dan akurasi sistem semakin baik.

\section{REFERENSI}

[1] Aggarwal, C. C., \& Han, J. (Eds.). (2014). Frequent Pattern Mining. Springer.
[2] Kenmogne, E. B. (2016). The Impact of the PatternGrowth Ordering on the Performances of Pattern Growth-Based Sequential Pattern Mining Algorithms. Computer and Information Science, 10(1), 23.

[3] Aggarwal, C. C. (2015). Data Mining: The Textbook. Springer.

[4] Fradkin, D., \& Mörchen, F. (2015). Mining Sequential Patterns for Classification. Knowledge and Information Systems, 45(3), 731-749.

[5] Straccia, U. (2016). Foundations of Fuzzy Logic and Semantic Web Languages. Chapman and Hall/CRC.

[6] Zabihi, F., Ramezan, M., Pedram, M. M., \& Memariani, A. (2011). Rule Extraction For Blood Donators With Fuzzy Sequential Pattern Mining. The Journal of Mathematics and Computer Science, 2(I).

[7] Chueh, H. E. (2010). Mining Target-Oriented Sequential Patterns With Time-Intervals. arXiv preprint arXiv:1009.0929.

[8] Huang, T. C. K. (2012). Mining The Change Of Customer Behavior In Fuzzy Time-Interval Sequential Patterns. Applied Soft Computing, 12(3), 1068-1086.

[9] Chen, Y. L., \& Huang, T. K. (2005). Discovering Fuzzy Time-Interval Sequential Patterns In Sequence Databases. IEEE Transactions on Systems, Man, and Cybernetics, Part B (Cybernetics), 35(5), 959-972. 